\title{
The Effects of Black and White Plastic Mulch on Soil Temperature and Yield of Crisphead Lettuce in Southern New England
}

\author{
Rahmatallah Gheshm ${ }^{1}$ and Rebecca Nelson Brown ${ }^{1}$
}

ADDITIONAL INDEX wORDs. black polyethylene mulch, canopy growth, head size, Lactuca sativa, white-on-black mulch

Summary. Annually, Americans consume an average of $24.5 \mathrm{lb}$ of lettuce (Lactuca sativa) per capita, more than half of which is head lettuce. This study examined the impacts of using black and white-on-black polyethylene mulches on three crisphead lettuce cultivars for spring production in the open field, with data collected on the soil temperature and lettuce yields. Black polyethylene, white-on-black polyethylene, and bare ground were compared for effects on soil temperature, lettuce yields, and lettuce head height and diameter. Mean soil temperatures at a $5 \mathrm{~cm}$ depth were $18.9^{\circ} \mathrm{C}$ under black polyethylene, $17.7^{\circ} \mathrm{C}$ under white-on-black polyethylene, and $17.1^{\circ} \mathrm{C}$ in bare ground plots. Changes in the lettuce canopy size presented a similar trend over the growing season in all treatments. Both mulch type and cultivar significantly $(P<\mathbf{0 . 0 1})$ affected the canopy growth in head lettuce. Lettuce on black polyethylene mulch grew significantly $(P<0.01)$ faster than lettuce on white-on-black polyethylene or bare ground. However, the black and white-onblack mulches produced similar yields, averaging 5.76 and $5.71 \mathrm{~kg} \cdot \mathrm{m}^{-2}$, respectively. Meanwhile, bare ground plot yields were significantly $(P<0.01)$ lower at $4.57 \mathrm{~kg} \cdot \mathrm{m}^{-2}$. Cultivar rank order was consistent across treatments, and Crispino and Garmsir at 5.82 and $5.47 \mathrm{~kg} \cdot \mathrm{m}^{-2}$ fresh weight had significantly higher yields than Nevada at $4.75 \mathrm{~kg} \cdot \mathrm{m}^{-2}(P<0.01)$.

$\mathrm{L}$ ettuce (Lactuca sativa) is one of the most important commercial leafy vegetables in the United States. Annually, Americans eat an average of around $24.5 \mathrm{lb}$ of lettuce per capita, and more than $50 \%$ of the lettuce consumed in 2018 was head lettuce $(12.3$ out of $24.5 \mathrm{lb}$ ) [U.S. Department of Agriculture (USDA), 2019a]. In 2017, about 147,396 acres of crisphead lettuce was grown in the United States, primarily in California and Arizona (USDA, 2019b). New England is the national leader in per capita vegetable consumption (Produce for Better Health Foundation, 2015). Two important issues for consumers

$\overline{\text { Received for publication } 16 \text { June 2020. Accepted for }}$ publication 6 Oct. 2020

Published online 9 November 2020

${ }^{1}$ Department of Plant Sciences and Entomology, University of Rhode Island, Kingston, RI 02881

We acknowledge the Rhode Island Agricultural Experiment Station for financial support.

We thank Timothy Sherman for help with fieldwork.

R.G. is a Post doctoral Fellow.

R.N.B. is the corresponding author. E-mail: brownreb@ uri.edu.

This is an open access article distributed under the CC BY-NC-ND license (https://creativecommons.org/ licenses/by-nc-nd/4.0/).

https://doi.org/10.21273/HORTTECH04674-20 are the freshness of vegetables and the price (Martinez et al., 2010). Urban areas of the northeastern United States create a large market for lettuce, and local production can significantly reduce the carbon footprint of supplying these markets (Plawecki et al., 2014). The increasing cost of shipping and consumers who value quality and freshness have increased demand for locally grown vegetables (Bloom et al., 2018) and have made lettuce a viable crop for the eastern United States, despite higher costs of production. The northeastern U.S. region, which includes New England, ranked second for both the number of farms with commodity sales direct to consumers and the value of sales (USDA, 2016). In 2017, nearly 650 farms in New England reported growing head lettuce, for a total of almost 300 acres harvested (USDA, $2019 b$ ). These values likely underestimate total production, as many small farms in New England grow head lettuce in plantings of less than one tenth of an acre as part of diversified vegetable production, and underreporting is a known problem. The crisphead lettuce market class includes two subtypes, iceberg and Batavia (Simko et al., 2014). The iceberg subtype is grown by the California and Arizona lettuce industries, and it dominates the wholesale market in the United States (Simko et al., 2014; USDA, 2004). However, most crisphead lettuce grown for local markets in the United States, and for all markets in other regions, is more like the Batavia subtype (Ryder, 1999).

Lettuce is a cool-season vegetable crop with an optimal air temperature of $23{ }^{\circ} \mathrm{C}$ and an optimal root temperature of $19{ }^{\circ} \mathrm{C}$ (Fazil Elahi et al., 2017). Daily mean air temperatures above $28{ }^{\circ} \mathrm{C}$ can cause bitterness, bolting, poor heading, and tip burn of lettuce (Turini et al., 2011; Whitaker et al., 1974), but damage can be prevented if temperatures in the root zone are near optimal (Jie and Kong, 1998). In warm and humid environments, the full expression of lettuce yield potential is not achievable (Vargas et al., 2018). In general, heading lettuces, such as crisphead, are more susceptible to both tip burn and frost injury than loose-leaf lettuces. Climate change is extending the frost-free period in the northeastern

\begin{tabular}{lllc}
\hline $\begin{array}{l}\text { Units } \\
\text { To convert U.S. to SI, } \\
\text { multiply by }\end{array}$ & U.S. unit & SI unit & $\begin{array}{l}\text { To convert SI to U.S., } \\
\text { multiply by }\end{array}$ \\
\hline 0.4047 & $\mathrm{acre}(\mathrm{s})$ & $\mathrm{ha}$ & 2.4711 \\
0.3048 & $\mathrm{Ft}$ & $\mathrm{m}$ & 3.2808 \\
0.0929 & $\mathrm{ft}^{2}$ & $\mathrm{~m}^{2}$ & 10.7639 \\
0.0283 & $\mathrm{ft}^{3}$ & $\mathrm{~m}^{3}$ & 35.3147 \\
3.7854 & gal & $\mathrm{L}$ & 0.2642 \\
2.54 & inch $(\mathrm{es})$ & $\mathrm{cm}^{3}$ & 0.3937 \\
16.3871 & inch & $\mathrm{cm}^{3}$ & 0.0610 \\
0.0418 & langley(s) & $\mathrm{MJ} \cdot \mathrm{m}^{-2}$ & 23.9006 \\
0.4536 & $\mathrm{lb}$ & $\mathrm{kg}$ & 2.2046 \\
1.1209 & $\mathrm{lb} / \mathrm{acre}$ & $\mathrm{kg} \cdot \mathrm{ha}^{-1}$ & 0.8922 \\
4.8824 & $\mathrm{lb} / \mathrm{ft}^{2}$ & $\mathrm{~kg} \cdot \mathrm{m}^{-2}$ & 0.2048 \\
0.0254 & $\mathrm{mil}(\mathrm{s})$ & $\mathrm{mm}$ & 39.3701 \\
305.1517 & $\mathrm{oz} / \mathrm{ft}^{2}$ & $\mathrm{~g} \cdot \mathrm{m}^{-2}$ & 0.0033 \\
$\left({ }^{\circ} \mathrm{F}-32\right) \div 1.8$ & ${ }^{\circ} \mathrm{F}$ & ${ }^{\circ} \mathrm{C}$ & $\left({ }^{\circ} \mathrm{C} \times 1.8\right)+32$
\end{tabular}


United States, lengthening the harvest season for lettuce. However, prolonged periods of spring rains delay planting and complicate the production of spring head lettuce (Wolfe et al., 2018). Head lettuces are the slowest to mature (Lee et al., 2015), increasing the risks that delayed spring planting will result in exposure to above-optimum temperatures before the heads reach harvestable size. Risks are increased in areas such as northeastern North America, where aboveoptimum temperatures occur during periods where daylength exceeds $13 \mathrm{~h}$ (Rappaport and Wittwer, 1956). Cultivars with reduced vigor, high heading tendency, and tolerance to heat stress are recommended (Waycott and Ryder, 1992). Modern Imperial-type iceberg lettuce cultivars were developed for the cool-climate production areas of California and Arizona (Ryder, 1999) and are more susceptible to bolting and development of puffy heads than the older Great Lakes- and Bataviatype cultivars (Jenni and Yan, 2009). Crisphead lettuces grown outside the primary production areas are more like the 'Great Lakes' and 'Batavia' types than to the 'Imperial' type.

Lettuce is typically grown on bare soil in New England, but adopting raised beds covered with plastic mulch would allow farmers to create beds in the fall for spring planting, avoiding delays from spring rains. Plastic mulches provide multiple benefits, including serving as a physical barrier against soil erosion, reducing water evaporation from the soil, buffering against temperature fluctuations, suppressing weeds, and improving foliage quality (Lamont, 2005; Vargas et al., 2018). Mulch films alter the flow of thermal energy between the air and the rhizosphere (Rosenberg et al., 1983; Tarara, 2000) By modifying the radiation budget, plastic mulches directly affect the rhizosphere microclimate. The soil temperature under plastic mulch depends on the optical properties of the mulch material, and each material has a different reflectivity and absorptivity (Pramanik et al., 2015). Darkcolored mulches will absorb more solar radiation and emit longwave radiation toward both the air and soil. Plastic mulches, regardless of color, warm the soil quickly and increase early plant development in the colder months. The soil under white and reflective films remains cooler than soil under black, dark, and clear plastic films (Snyder et al., 2015). The warming effects of mulch films are beneficial in the spring when soil temperatures are below optimum, but these effects could be hazardous to plant growth later in the season (Snyder et al., 2015).

Plastic mulch has the potential to improve yields and quality of spring lettuce, and to facilitate early spring planting; but choosing the type of plastic mulch is complicated by the need to balance the risks of belowoptimum temperatures early in the season with those of above-optimum temperatures during heading. The objective of this research was to examine the effects of black and white polyethylene mulches on root zone temperatures and the growth of three crisphead lettuce cultivars during the spring production season in a northeastern U.S. coastal climate.

\section{Materials and methods}

The experiment was conducted as a spring planting at the University of Rhode Island's Gardener Crops Research Center in Kingston. The field soil is Bridgehampton silt loam, with a $\mathrm{pH}$ of 5.9 and $3.6 \%$ organic matter. In the growing season, air temperatures ranged from a minimum of $6.9{ }^{\circ} \mathrm{C}$ in May to a maximum of $26.6{ }^{\circ} \mathrm{C}$ in June, with an average daytime temperature of $22.7^{\circ} \mathrm{C}$ and an average night temperature of $10.4^{\circ} \mathrm{C}$. Average solar radiation was $19.5 \mathrm{MJ} \cdot \mathrm{m}^{-2} \cdot \mathrm{d}^{-1}$. Cumulative solar radiation over the $56 \mathrm{~d}$ of the experiment was $1096 \mathrm{MJ} \cdot \mathrm{m}^{-2}$. Precipitation during the experimental period was 7.1 inches. The experimental field was irrigated four times, each time for $6 \mathrm{~h}$. Total amount of irrigation was $18.5 \mathrm{~m}^{3}$, equivalent to an additional 6.7 inches of precipitation.

On 23 Mar. 2017, lettuce seeds of three crisphead lettuce cultivars, Nevada, Crispino, and Garmsir, were seeded into 102-cell plug trays with a cell volume of $22 \mathrm{~cm}^{3}$ (Landmark Plastics, Akron, $\mathrm{OH}$ ) filled with a bark- and peatmoss-based greenhouse medium with starter nutrients (Metromix 510; Sun Gro Horticulture, Agawam, MA). 'Nevada' is a green summer crisp or Batavian lettuce, introduced by Vilmorin (Paris, France) in 1991 and developed for heat tolerance (Holmes et al., 2019) 'Crispino' was released before 1985, probably in Europe (Reppenhorst, 1986). It is sold as an iceberg-type crisphead lettuce to home gardeners and market farmers in the United States, but it is not used in the primary wholesale production areas (Simko et al., 2014). 'Crispino' is described in seed catalogs as adaptable and well suited to climates that are not ideal for the Imperial-type cultivars. Seeds of 'Nevada' and 'Crispino' were obtained from Johnny's Selected Seeds (Albion, $\mathrm{ME}$ ). 'Garmsir' is a crisphead lettuce adapted to arid climates; seeds were obtained from the Falat Iran Company (Tehran, Iran). The planted trays were kept for $10 \mathrm{~d}$ in the greenhouse with a constant temperature of $25^{\circ} \mathrm{C}$, then transplants were grown in uncontrolled conditions in a high tunnel for $30 \mathrm{~d}$. On 8 May, plants were transplanted into raised beds on 5 - $\mathrm{ft}$ centers. Each bed had two rows of lettuce $40 \mathrm{~cm}$ apart. In-row spacing between plants was $30 \mathrm{~cm}(8.3$ plants $/ \mathrm{m}^{2}$ ). Fertilizers were broadcast and incorporated during bed formation to provide $96 \mathrm{lb} /$ acre nitrogen, $35 \mathrm{lb} /$ acre phosphorous, and $58 \mathrm{lb} /$ acre potassium using urea $(46 \mathrm{~N}-0 \mathrm{P}-0 \mathrm{~K})$, potassium sulfate $(0 \mathrm{~N}-0 \mathrm{P}-44.9 \mathrm{~K})$, and blended fertilizer $(12 \mathrm{~N}-10.5 \mathrm{P}-10.0 \mathrm{~K}$; Southern States Cooperative, Richmond, VA). Each bed had two lines of drip tape with 12-inch emitter spacing and a $0.25-\mathrm{gal} / \mathrm{h}$ flow rate (Chapin BTF; Jain Irrigation, Watertown, NY), spaced 10 inches apart beneath the mulch. Standard 1.0-mil microembossed black polyethylene mulch and 1.5-mil polyethylene white-onblack film (Berry Plastics, Evansville, IN) were laid using a mulch layer (2550; Rain-Flo Irrigation, East Earl, PA). Sixteen data loggers with integral sensors (iButton; Maxim Integrated, San Jose, CA) were placed between plants in the center of main plots at 2 inches below the soil surface. Air temperature loggers (also iButton) were installed in three different points of the field at a height of 10 inches above the bed surface and shaded from direct sunlight. Air and soil temperatures were recorded at 4-h intervals. Plants were watered immediately after transplanting and fertigated on 12 and 23 May 2017 with a water-soluble fertilizer (Aquatrols, Paulsboro, NJ) to provide a total 
of $25.3 \mathrm{lb} /$ acre nitrogen, $9 \mathrm{lb} / \mathrm{acre}$ phosphorus, and $18.9 \mathrm{lb} /$ acre potassium. Weeds in the bare ground plots were controlled by hand on 13 and 24
May. Weeds in other treatments were controlled by plastic mulch; alleys and buffers were mulched with locally sourced aged hardwood chips. Lettuce was harvested on 5 July when heads had fully formed (Fig. 1).

Our experimental design was a split-plot with four replications.
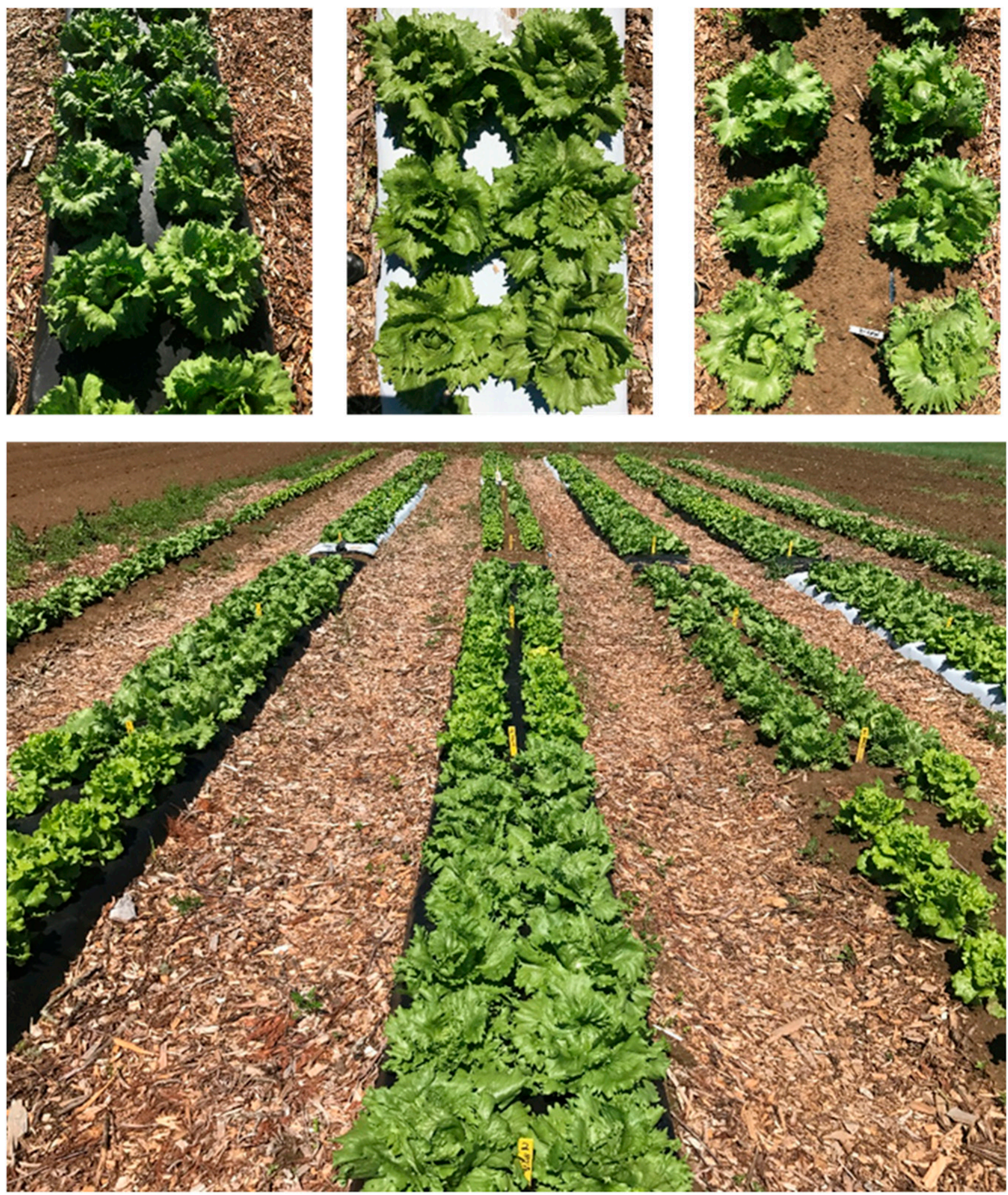

Fig. 1. Three head lettuce cultivars (Nevada, Crispino, and Garmsir) grown as a spring-to-summer crop on raised beds covered by black polyethylene mulch, white-on-black polyethylene mulch, and bare ground as a control in Rhode Island in Spring 2017. Top: Black plastic mulch (left), white-on-black plastic mulch (center), bare ground (right). Bottom: Overview of experiment field. Photos were taken on 22 June 2017, $51 \mathrm{~d}$ after transplanting. 
Mulch treatments were applied as main plots, and cultivars applied as the subplots. The main plot treatments were completely randomized. The main plots were $6 \mathrm{~m}$ long; subplots were $2 \mathrm{~m}$ long. Raised bed width and height were 0.75 and $0.2 \mathrm{~m}$, respectively. The main plots were separated by an unplanted buffer $60 \mathrm{~cm}$ long. The main plot treatments were bare ground, black polyethylene mulch, and whiteon-black polyethylene film with the white layer facing upward.

Data were collected on soil temperature, canopy growth, yield, head height (vertical external diameter), head diameter, and plant dry weight (shoot only). Canopy growth was estimated using a variation of the method of Bumgarner et al. (2012). Every $10 \mathrm{~d}$ during vegetative growth, digital images were taken using a white quadrat $(35 \times 35 \mathrm{~cm})$ placed around two randomly selected plants in the middle of each subplot. Images were taken from a height of $60 \mathrm{~cm}$ above the quadrat, perpendicular to the ground. The percentage of the green cover was calculated using Canopeo (Patrignani and Ochsner, 2015) and converted to an area based on the quadrat area. The selected plants were also used to determine dry weights. Yield measurements were based on the entire subplot. At harvest, five trimmed heads were randomly selected from each subplot and used to determine head height and head diameter. Height was measured from the trimmed core base to the top of the head, while diameter was measured perpendicular to the core at the widest point. Measurements were made on intact heads. To measure dry weight, two heads per subplot were cut into small pieces and then dried in a forced-air dryer at $43{ }^{\circ} \mathrm{C}$.

Yield and plant size data were analyzed using the analysis of variance (ANOVA) and Duncan's multiple range tests in SAS (version 9.4; SAS Institute, Cary, NC). Canopy growth data were analyzed using repeatedmeasures ANOVA (PROC MIXED) and pairwise comparison of least squares means. Soil temperature data were analyzed as a completely randomized design (main plots only) and means separated with Tukey's test. Graphs were drawn in Microsoft Office Excel (version 2016; Microsoft Corp., Redmond, WA) and Veusz 3.1 (Sanders, 2019).

\section{Results and discussion}

EFFECTS OF MULCHES ON SOIL TEMPERATURES. The mean soil temperature was $18.9{ }^{\circ} \mathrm{C}$ in black polyethylene mulched plots, which was significantly $(P<0.01)$ warmer than soil temperature in plots mulched with white-on-black polyethylene $\left(17.7^{\circ} \mathrm{C}\right)$ and bare ground plots $\left(17.1^{\circ} \mathrm{C}\right)$. Daily mean temperatures ranged from 11.0 to $24.7^{\circ} \mathrm{C}$ under black mulch and from 10.2 to $23.4^{\circ} \mathrm{C}$ under white-on-black mulch. Bare ground soil temperatures ranged from 9.9 to $23.4{ }^{\circ} \mathrm{C}$. (Fig. 2) Mean daily high temperatures were $21.3^{\circ} \mathrm{C}$ for black mulch, $20.2^{\circ} \mathrm{C}$ for whiteon-black mulch, and $20.6^{\circ} \mathrm{C}$ for bare ground. Mean daily low temperatures were $16.5{ }^{\circ} \mathrm{C}$ for black mulch, $15.5{ }^{\circ} \mathrm{C}$ for white-on-black mulch, and $15.1{ }^{\circ} \mathrm{C}$ for bare ground. These
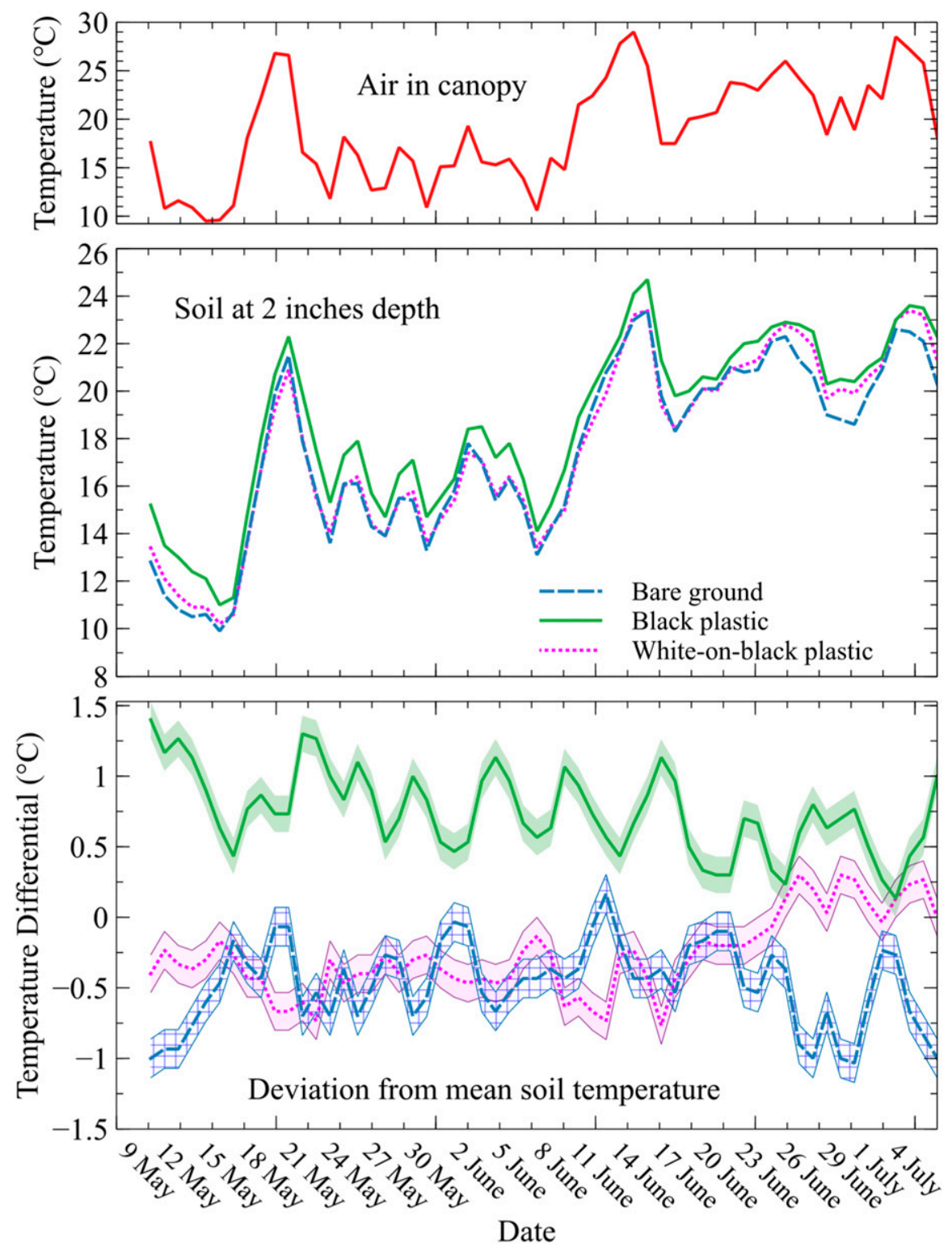

Fig. 2. Daily mean air and soil temperatures in head lettuce plots mulched with black or white-on-black polyethylene film, and bare ground during Spring 2017. Air temperature was measured at 10 inches $(25.4 \mathrm{~cm})$ above the bed surface. Soil temperature was measured at 2 inches $(5.1 \mathrm{~cm})$ in depth. Temperature was measured every $4 \mathrm{~h}$ from 8 May to 5 July; readings from each 24 -h period were averaged to calculate daily means. Lines represent the average of three plots. Differentials between soil temperatures in the three treatments were calculated as the difference between the grand mean across all treatments and the treatment means for each date. Bands represent standard error for each treatment mean; $\left(1.8 \times{ }^{\circ} \mathrm{C}\right)+32={ }^{\circ} \mathrm{F}$. 
values suggest that the mulches did provide some degree of buffering, although the differences are not statistically significant, and variation around the means was homogeneous. Many studies have found that black plastic mulch increases soil temperatures (Lamont, 2005), and it is widely used to enhance the growth of heatloving crops. For crops such as head lettuce, which are vulnerable to heat stress, the white-on-black film is generally recommended to avoid harmful soil warming (Snyder et al., 2015; Vargas et al., 2018). However, Jenni et al. (2003) found that infrared (IR) transmitting mulch increased yields over both bare ground and reflective mulch in spring-to-summer head lettuce in Ontario, Canada. Lettuce growth rate is highly correlated with both accumulated growing degree days (GDD) and accumulated photosynthetically active radiation $(P A R)$, especially in the heading stage where the growth rate is exponential (Salomez and Hofman, 2007). However, the root zone temperature effect in lettuce is also substantial because of the soil temperature effects on assimilation partitioning in addition to water and nutrient uptake (Fazil Elahi et al., 2017; Sun et al., 2016). Fazil Elahi et al. (2017) demonstrated that the optimal ambient root zone temperature for head lettuce is $19^{\circ} \mathrm{C}$, similar to the average soil temperature under black polyethylene mulch in this experiment. While the average temperature over the experiment as a whole in the black mulch treatment did not exceed the optimal temperature for lettuce, the 24-h average exceeded the optimal temperature on day 7 (Fig. 2). The effects of black and white-on-black film on root zone temperature is qualitatively similar, but values of root zone temperature achieved are lower for white-on-black film (Fig. 2). White-on-black plastic resulted in root zone temperatures like those in bare ground plots until 24 June, when precipitation decreased the temperature of the bare ground plots. Over the entire study, nightime low temperatures tended to be slightly warmer under white-onblack mulch than in bare ground plots, while daytime high temperatures were slightly cooler.

EFFECTS OF MULCHES AND CULTIVARS ON LETTUCE CANOPY SIZE. Mulch type significantly $(P<0.01)$ affected canopy growth, and there were significant $(P<0.01)$ differences in the growth rate between cultivars. Pairwise comparison of least squares means showed that lettuce on black mulch grew significantly $(P<0.01)$ faster than lettuce on white-on-black mulch or bare ground. White-onblack mulch affected growth rate similarly to bare ground (Fig. 3). Jenni et al. (2003) similarly found that crisphead lettuce grown on IR transmitting mulch reached marketable size in fewer days after transplanting than the same cultivar grown on white-on-black mulch or bare ground. Mulch effects were consistent across all cultivars. The cultivar Nevada demonstrated significantly slower growth $(P<0.01)$ than Crispino or Garmsir, which were similar (Fig. 4). At the last measurement on 27 June, the lettuce canopy covered more than $74 \%$ of the soil surface in black mulch plots. At the same time,

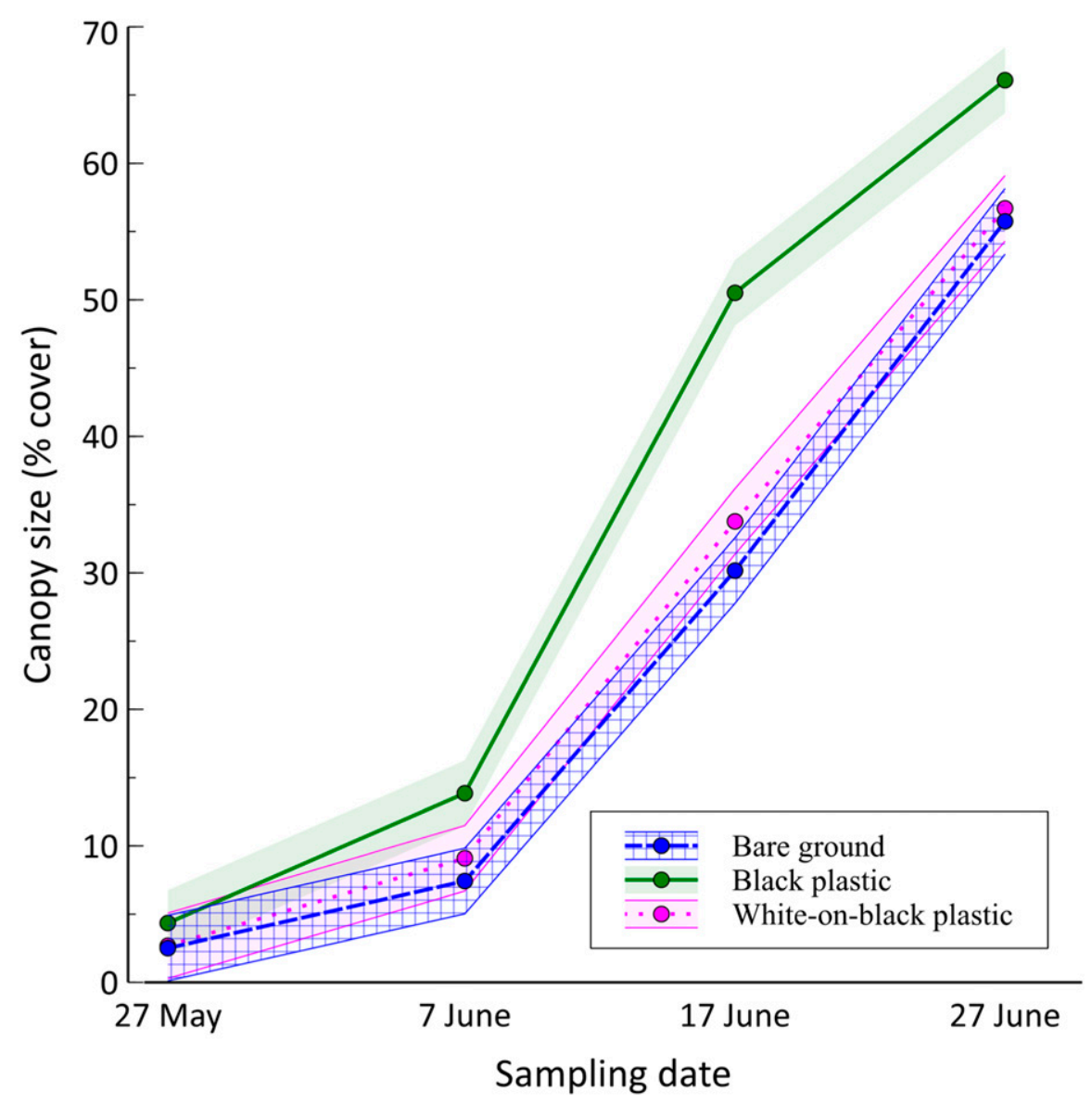

Fig. 3. Change in canopy size of head lettuce over time for three treatments of soil cover, including black plastic mulch, white-on-black plastic mulch, and bare ground as a control, grown in the field in Kingston, RI during Spring 2017. Data are averages across four replications. Means were significantly different $(P<0.01)$. Bands indicate $95 \%$ confidence intervals. only $67 \%$ and $64 \%$ of the soil surface was covered in the white-on-black mulch and bare ground plots, respectively. Higher soil temperature appears to have increased canopy growth. Dufault et al. (2009) found a similar connection between soil temperature and growth rate in romaine lettuce. Brault et al. (2002) reported that coated paper mulches and white-on-black polyethylene mulch significantly increased growth rate of head lettuce relative to the bare soil control, and leaves started to cup faster under mulched treatments. Interestingly, they found that all inorganic mulches tested had this effect, while we found that only black polyethylene mulch increased growth rate.

The EFFECTS OF MULCHES AND CULTIVARS ON LETTUCE YIELDS AND HEAD SIZE. Both black mulch and white-on-black mulch significantly $(P<0.01)$ increased lettuce yields in 
comparison with bare ground (Table 1). Dry weight and head diameter were unaffected by the mulch treatments (Table 1). Jenni et al. (2003) also found that IR transmitting and white-on-black mulches increased yields relative to bare ground; but in their study, mulch did significantly increase head diameter. Toth et al. (2008) reported that marketable yields of head lettuce grown on polyethylene film were significantly greater than yields of lettuce grown with hay, straw, or paper mulches or in uncovered soil. Using mulches and rowcovers on lettuce increased yields in Iowa, but plant dry weight was unaffected by increasing the soil and air temperature (Nair and Hovlovic, 2013). Brault et al. (2002) reported that inorganic mulches including plastics and degradable paper mulches significantly increased lettuce yield in comparison with bare ground. Siwek et al. (2007)

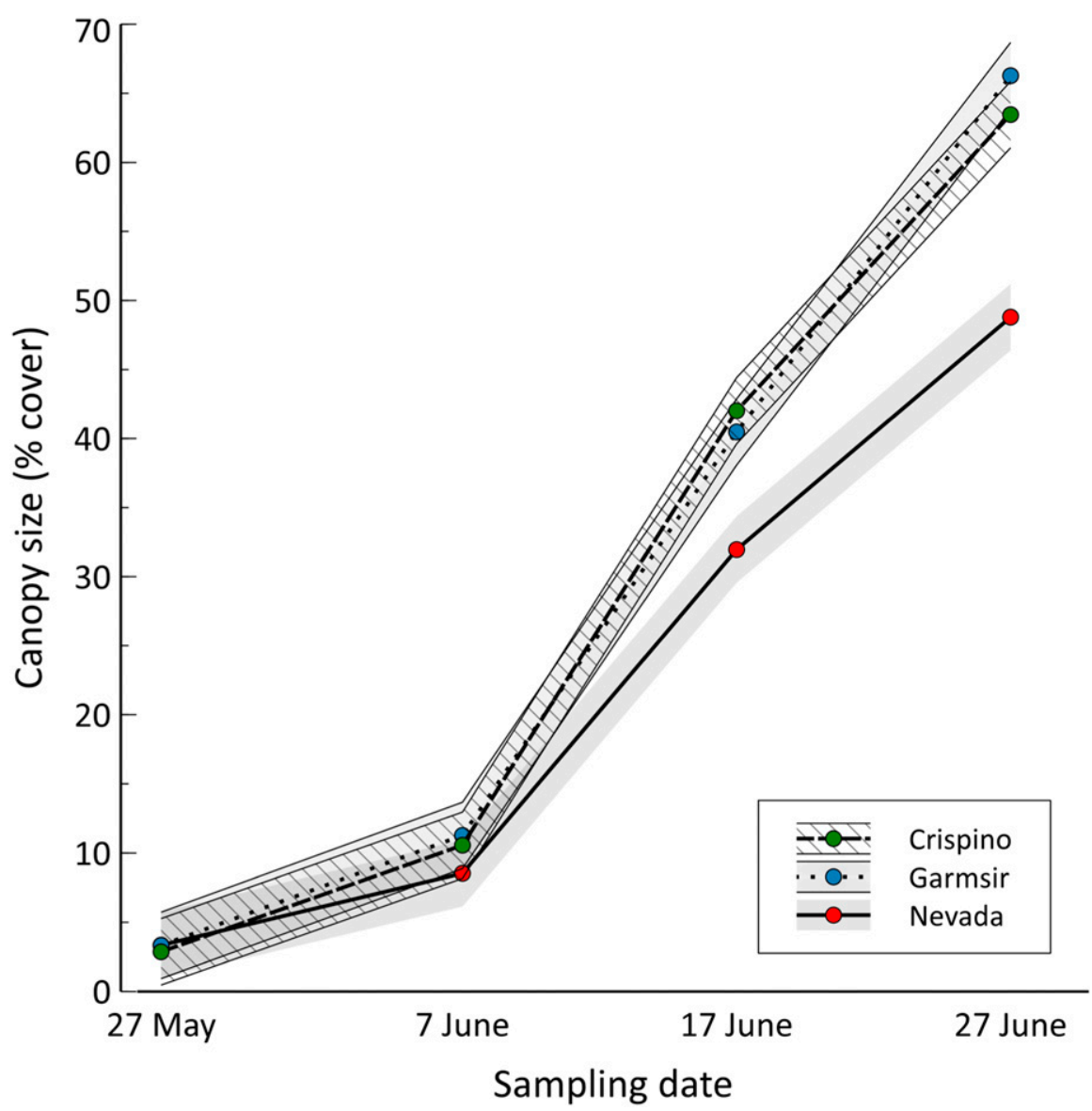

Fig. 4. Change in canopy size, measured as covered soil percentage, over time for three head lettuce cultivars (Nevada, Crispino, and Garmsir) grown in the field in Kingston, RI during Spring 2017. Data are averages across four replications. Means were significantly different $(P<0.01)$. Bands indicate $95 \%$ confidence intervals.

Table 1. The effect of color of polyethylene mulch on the yield, dry weight, and external head diameter of crisphead lettuce grown in the field in Kingston, RI during Spring 2017 . Lettuce was planted at a density of 8.3 plants $/ \mathrm{m}^{2}(0.77$ plant $\left./ \mathrm{ft}^{2}\right)$.

\begin{tabular}{lccc}
\hline Mulch & $\begin{array}{c}\text { Yield } \\
\left(\mathbf{k g} \cdot \mathbf{m}^{-2}\right)^{\mathbf{z}}\end{array}$ & $\begin{array}{c}\text { Dry wt } \\
\left(\mathbf{g} \cdot \mathbf{m}^{-2}\right)^{\mathbf{z}}\end{array}$ & $\begin{array}{c}\text { Head diam } \\
(\mathbf{c m})^{\mathbf{z}}\end{array}$ \\
\hline Black polyethylene mulch & $5.76 \mathrm{a}^{\mathrm{y}}$ & $170 \mathrm{a}$ & $18.78 \mathrm{a}$ \\
White-on-black polyethylene mulch & $5.71 \mathrm{a}$ & $150 \mathrm{a}$ & $19.22 \mathrm{a}$ \\
Bare ground & $4.57 \mathrm{~b}$ & $160 \mathrm{a}$ & $19.33 \mathrm{a}$ \\
\hline
\end{tabular}

${ }^{\mathrm{z}} 1 \mathrm{~kg} \cdot \mathrm{m}^{-2}=0.2048 \mathrm{lb} / \mathrm{ft}^{2} ; \mathrm{l} \mathrm{g} \cdot \mathrm{m}^{-2}=0.0033 \mathrm{oz} / \mathrm{ft}^{2} ; 1 \mathrm{~cm}=0.3937 \mathrm{inch}$.

${ }^{\mathrm{y}}$ Different letters indicate significant difference at $P<0.01$ according to Duncan's multiple range test. reported that regardless of mulch color, the marketable yield of lettuce heads cultivated on mulch was significantly higher than in the bare ground. Our results suggest that the increases in yield found in this and other studies are not a result of increased average soil temperatures, although increased soil temperatures do correlate with increased yields in romaine lettuce (Gheshm and Brown, 2020). Increased yields may be due to increased nutrient availability, particularly nitrate, as plastic mulches prevent leaching following heavy rainfall, and lettuce has been shown to increase yields when nitrate leaching is reduced (Verdial et al., 2001). Other possible explanations for increased yield in polyethylene-mulched plots include reduced root stress from soil saturation following heavy rainfall events, reduced soil compaction, and increased carbon dioxide $\left(\mathrm{CO}_{2}\right)$ levels in the lettuce canopy because the impermeable plastic film causes all $\mathrm{CO}_{2}$ released from the soil to be vented through the planting holes, directly into the canopy (Lamont, 1993).

Cultivar effects. All cultivars in this experiment were developed for full-sized head production and required similar time to maturity. ANOVA showed that 'Crispino' and 'Garmsir' yielded significantly more than 'Nevada' $[P<0.01$ (Table 2)]. 'Garmsir' yield did not differ significantly from 'Crispino'. Results also showed that the dry weight and head diameter did not differ among cultivars (Table 2 ).

Results obtained from the ANOVA showed no significant interactions between cultivars and mulch for yield, dry weight, and head diameter. However, head height (vertical diameter) was affected by the interaction between mulch and cultivar. Mulch type had no effect on head height in 'Nevada' and 'Garmsir', but it significantly affected head height in 'Crispino', where heads from plants grown in black mulch were significantly taller than those from plants grown in white-on-black mulch or bare ground (Table 3 ). Cultivars did not differ significantly in vertical diameter of trimmed heads when grown on either black or white-onblack mulches, but Crispino heads were significantly shorter than the other cultivars when grown on bare ground (Table 3). Head height in 
Table 2. The effects of cultivar on the yield, dry weight, and external head diameter of crisphead lettuce grown in the field in Kingston, RI during Spring 2017. Lettuce was planted at a density of 8.3 plants $/ \mathrm{m}^{2}\left(0.77\right.$ plant $\left./ \mathrm{ft}^{2}\right)$.

\begin{tabular}{lccc}
\hline Cultivar & Yield $\left(\mathrm{kg} \cdot \mathrm{m}^{-2}\right)^{\mathrm{z}}$ & Dry wt $\left(\mathrm{g} \cdot \mathrm{m}^{-2}\right)^{\mathrm{z}}$ & Head diam $(\mathrm{cm})^{\mathrm{z}}$ \\
\hline Nevada & $4.75 \mathrm{~b}^{\mathrm{y}}$ & $150 \mathrm{a}$ & $18.03 \mathrm{a}$ \\
Crispino & $5.82 \mathrm{a}$ & $160 \mathrm{a}$ & $19.35 \mathrm{a}$ \\
Garmsir & $5.47 \mathrm{a}$ & $160 \mathrm{a}$ & $19.85 \mathrm{a}$ \\
\hline
\end{tabular}

${ }^{\mathrm{z}} 1 \mathrm{~kg} \cdot \mathrm{m}^{-2}=0.2048 \mathrm{lb} / \mathrm{ft}^{2} ; \mathrm{l} \mathrm{g} \cdot \mathrm{m}^{-2}=0.0033 \mathrm{oz} / \mathrm{ft}^{2} ; \mathrm{l} \mathrm{cm}=0.3937$ inch.

${ }^{y}$ Different letters indicate significant difference at $P<0.01$ according to Duncan's multiple range test.

Table 3. The effects of cultivar and polyethylene mulch color on head height (external vertical diameter) across all mulch treatments and three crisphead lettuce cultivars grown in the field in Kingston, RI during Spring 2017.

\begin{tabular}{|c|c|c|c|}
\hline \multirow[b]{2}{*}{ Treatment } & \multicolumn{3}{|c|}{ Cultivar } \\
\hline & Nevada & Crispino & Garmsir \\
\hline Mulch & \multicolumn{3}{|c|}{$\mathrm{Ht}(\mathrm{cm})^{\mathrm{z}}$} \\
\hline Black polyethylene mulch & $23.0 \mathrm{~A} \mathrm{a}^{\mathrm{y}}$ & $24.1 \mathrm{~B} \mathrm{a}$ & $22.9 \mathrm{~A} \mathrm{a}$ \\
\hline White-on-black polyethylene mulch & $21.6 \mathrm{~A} \mathrm{a}$ & $21.2 \mathrm{~A} \mathrm{a}$ & $21.5 \mathrm{~A} \mathrm{a}$ \\
\hline Bare ground & $23.0 \mathrm{~A} \mathrm{a}$ & $19.5 \mathrm{~A} \mathrm{~b}$ & $21.9 \mathrm{~A} \mathrm{a}$ \\
\hline
\end{tabular}

${ }^{\mathrm{z}} 1 \mathrm{~cm}=0.3937$ inch.

${ }^{y}$ Different letters indicate significant difference at $P<0.01$ according to Duncan's multiple range test. Capital letters indicate differences between mulches (rows within a column), and lowercase letters indicate differences between cultivars (columns within a row).

'Crispino' varied by $4.6 \mathrm{~cm}$ across treatments, as compared with only $1.4 \mathrm{~cm}$ in 'Nevada' and 'Garmsir'. We did not directly measure stem length inside the lettuce heads, but changes in the rate of stem elongation are the most likely causes of differences in vertical head diameter within a single cultivar. The rate of stem elongation in lettuce has been shown to be very sensitive to root zone temperature, with stem elongation increasing as temperatures increase (Al Said et al., 2018). This stem elongation is independent of bolting, and genotypes are known to differ in response to temperature (Jenni and Yan, 2009). Our results suggest that rate of stem elongation in 'Crispino' may be more sensitive to changes in root zone temperature than in the other cultivars in this study.

\section{Conclusions}

Using polyethylene mulch significantly increased lettuce yields relative to growing in bare ground. Black mulch significantly increased soil temperature, while temperatures under white-on-black mulch were like those in bare ground plots. However, the increased temperatures under black mulch did not translate to increased yields relative to white-onblack mulch, suggesting that yield increases were caused by some other effect of the mulch. This study was not designed to measure other effects, but one likely possibility is that the plastic film prevented soils in the lettuce root zone from becoming saturated following rain events, reducing root stress and nitrate leaching (Lamont, 1993; Verdial et al., 2001). The lack of harmful effects on lettuce yield from polyethylene mulch show that growing lettuce on mulch-covered beds is a viable practice in New England. The use of mulch would allow growers to prepare beds in the late fall, facilitating planting in the spring.

In this study polyethylene mulch increased yields by just over $1 \mathrm{~kg} \cdot \mathrm{m}^{-2}$ relative to bare ground. Mulches also eliminate the need for hand weeding, reducing weed-control costs. Using mulch increases bed preparation costs by $\$ 0.08 / \mathrm{m}^{2}$ for black polyethylene, and $\$ 0.10 / \mathrm{m}^{2}$ for white-on-black polyethylene, but saves $\$ 0.36 / \mathrm{m}^{2}$ in weed control costs [estimate based on hand cultivation]. Mulch removal and disposal is estimated to cost $\$ 0.08 /$ $\mathrm{m}^{2}$ (Chen et al., 2018). At a retail price of $\$ 2 / \mathrm{lb}$, using black mulch would increase grower net profits by $\$ 5.44 / \mathrm{m}^{2}$, while using white-onblack would increase net profits by $\$ 5.20 / \mathrm{m}^{2}$. Black plastic mulch would be most profitable unless the grower planned to follow the spring-lettuce crop with a summer-to-fall cool-season crop that would benefit from the soil cooling provided by white-on-black plastic mulch.

Heat tolerance is often a primary consideration when selecting lettuce cultivars for the northeastern United States (Jenni and Yan, 2009). Bolting is a major cause of yield loss. The lack of mulch effect on head height in Nevada and Garmsir suggests that these cultivars are less likely to bolt. Yield is a primary consideration when selecting cultivars for all environments, and Crispino and Garmsir yielded significantly more than Nevada across all mulch treatments. When all cultivar traits are considered, Garmsir appears to be the best choice. Unfortunately this Iranian cultivar is not currently available in the United States. Thus we recommend that growers in the northeastern United States use 'Crispino' in combination with white-on-black mulch to maximize yields while minimizing stem elongation.

\section{Literature cited}

Al-Said, F., P. Hadley, S. Pearson, M.M. Khan, and Q. Iqbal. 2018. Effect of high temperature and exposure duration on stem elongation of iceberg lettuce. Pak. J. Agr. Sci. 55:95-101.

Bloom, D., D. Lelekacs, and R. Dunning. 2018. Local food systems: Clarifying current research. 30 June 2019. <https:// content.ces.ncsu.edu/local-food-systemsclarifying-current-research\#img_dialog_ $5613>$.

Brault, D., K.A. Stewart, and S. Jenni. 2002. Growth, development, and yield of head lettuce cultivated on paper and polyethylene mulch. HortScience 37:9294.

Bumgarner, N.R., W.S. Miller, and M.D. Kleinhenz. 2012. Digital image analysis to supplement direct measures of lettuce biomass. HortTechnology 22:547-555.

Chen, K., S. Galinato, S. Ghimire, S. MacDonald, T. Marsh, C. Miles, P. Tozer, and M. Velandia. 2018. Mulch calculator. Rep. No. LCA/SC-2018-01. 24 Aug. 2020. <https://ag.tennessee. edu/biodegradablemulch/Documents/ Chen-Mulch-calculcator-introduction. pdf>.

Dufault, R.J., B. Ward, and R.L. Hassell. 2009. Dynamic relationships between field temperatures and romaine lettuce yield and head quality. Scientia Hort. 120:452-459. 
Fazil Elahi, W.F., D. Ahmad, and M.C. Husain. 2017. Effects of root zone cooling on butterhead lettuce grown in tropical conditions in a coir-perlite mixture. Hort. Environ. Biotechnol. 58:1-4.

Gheshm, R. and R.N. Brown. 2020. Compost and black polyethylene mulches improve spring production of romaine lettuce in southern New England. HortTechnology 30:510-518.

Holmes, S.C., D.E. Wells, J.M. Pickens, and J.M. Kemble. 2019. Selection of heat tolerant lettuce (Lactuca sativa L.) cultivars grown in deep water culture and their marketability. Horticulturae 5:50.

Jenni, S., J.F. Dubuc, and K.W. Stewart. 2003. Plastic mulches and row covers for early and midseason crisphead lettuce produced on organic soils. Can. J. Plant Sci. 83:921-929.

Jenni, S. and W. Yan. 2009. Genotype by environment interactions of heat stress disorder resistance in crisphead lettuce. Plant Breed. 128:374-380, doi: 10.1111/ j.1439-0523.2009.01657.x.

Jie, H. and L.S. Kong. 1998. Growth and photosynthetic characteristics of lettuce (Lactuca sativa L.) under fluctuating hot ambient temperatures with the manipulation of cool root-zone temperature. J. Plant Physiol. 152:387-391.

Lamont, W.J. 1993. Plastic mulches for the production of vegetable crops. HortTechnology 3:35-39.

Lamont, W.J. 2005. Plastics: Modifying the microclimate for the production of vegetable crops. HortTechnology 15:477481.

Lee, A., F. Liao, and H. Lo. 2015. Temperature, daylength, and cultivar interact to affect the growth and yield of lettuce grown in high tunnels in subtropical regions. HortScience 50:1412-1418.

Martinez, S., M. Hand, M. Da Pra, S. Pollack, K. Ralston, T. Smith, S. Vogel, S. Clark, L. Lohr, S. Low, and C. Newman. 2010. Local food systems: Concepts, impacts, and issues. U.S. Dept. Agric., Econ. Res. Serv., Econ. Res. Rpt. 96635.

Nair, A. and B.J. Havlovic. 2013. Mulch and row cover affect lettuce production in high tunnels. Iowa State Res. Farm Prog. Rpt. 1864. 30 June 2019. <https://lib. dr.iastate.edu/farms_reports/1864/>.

Patrignani, A. and T.E. Ochsner. 2015. Canopeo: A powerful new tool for measuring fractional green canopy cover. Agron. J. 107:2312-2320.

Plawecki, R., R. Pirog, A. Montri, and M. Hamm. 2014. Comparative carbon foot- print assessment of winter lettuce production in two climatic zones for the Midwestern market. Renew. Agr. Food Syst. 29:310-318.

Pramanik, P., K.K. Bandyopadhyay, D. Bhaduri, R. Bhattacharyya, and $P$. Aggarwal. 2015. Effect of mulch on soil thermal regimes-A review. Intl. J. Agr. Environ. Biotechnol. 8:645-658.

Produce for Better Health Foundation. 2015. State of the plate, 2015 study on America's consumption of fruit and vegetables. 30 Jan. 2020. <https:// fruitsandveggies.org/wp-content/uploads/ 2019/05/2015-State_of_the_Plate.pdf $>$.

Rappaport, L. and S.H. Wittwer. 1956. Night temperature and photoperiod effects on flowering of leaf lettuce. Proc. Amer. Soc. Hort. Sci. 68:279-282.

Reppenhorst, M. 1986. Eissalatsorten fuer den Sommeranbau im Freiland [Ice lettuce cultivars for summer outdoor cultivation]. Rheinische Monatsschrift fuer Gemuese Obst Zierpflanzen 74:384.

Rosenberg, N.J., B.L. Blad, and S.B. Verma. 1983. Microclimate: The biological environment. Wiley, New York, NY.

Ryder, E.J. 1999. Lettuce, endive and chicory. CAB Intl., Wallingford, UK.

Salomez, J. and G. Hofman. 2007. A soil temperature/short-wave radiation growth model for butterhead lettuce under protected cultivation in Flanders. J. Plant Nutr. 30:397-410.

Sanders, J. 2019. Veusz-A scientific plotting package. 5 Dec. 2019. <https:// veusz.github.io/>.

Simko, I., R.J. Hayes, B. Mou, and J.D. McCreight. 2014. Lettuce and spinach. In: S. Smith, B. Diers, J. Specht, and B. Carver (eds.). Yield gains in major U.S. field crops. Crop Sci. Soc. Amer. (CSSA) Spec. Publ. 33:53-85. 10 June 2019. doi: 10.2135/cssaspecpub33.c4.

Siwek, P., A. Kalisz, and R. Wojciechowska. 2007. Effect of mulching with film of different colors made from original and recycled polyethylene on the yield of butterhead lettuce and celery. Folia Hort. 19:25-35.

Snyder, K., A. Grant, C. Murray, and B. Wolff. 2015. The effects of plastic mulch systems on soil temperature and moisture in central Ontario. HortTechnology 25:162-170.

Sun, J., N. Lu, H. Xu, T. Maruo, and S. Guo. 2016. Root zone cooling and exogenous spermidine root-pretreatment promoting Lactuca sativa L. growth and photosynthesis in the high-temperature season. Front. Plant Sci. 7:368.

Tarara, J.M. 2000. Microclimate modification with plastic mulch. HortScience 35:169-180.

Toth, N., S. Fabek, M. Herakćustić, I. Žutić, and J. Borošić. 2008. Organic soil mulching impacts on lettuce agronomic traits. Cereal Res. Commun. 36:395-398.

Turini, T., M. Cahn, M. Cantwell, L. Jackson, S. Koike, E. Natwick, R. Smith, K. Subbarao, and E. Takele. 2011. Iceberg lettuce production in California. 10 June 2019. <https://anrcatalog. ucanr.edu/Details.aspx?itemNo $=7215 \#$ FullDescription>.

U.S. Department of Agriculture. 2004. Lettuce shipping point and market inspection instructions. U.S. Dept. Agr., Agr. Marketing Serv., Washington, DC.

U.S. Department of Agriculture. 2016. 2015 Local food marketing practices survey. U.S. Dept. Agr., Natl. Agr. Stat. Serv., Washington, DC.

U.S. Department of Agriculture. 2019a. Vegetables 2018 summary. U.S. Dept. Agr., Natl. Agr. Stat. Serv., Washington, DC.

U.S. Department of Agriculture. 2019b. 2017 Census of agriculture. U.S. Dept. Agr., Nat. Agr. Stat. Serv., Washington, DC.

Vargas, P., A. Zecchini, R. Soares, L. Duarte, and E. Silva. 2018. Performance of crispy lettuce cultivars in different soil covers. Comun. Sci. 8:514-520.

Verdial, M.F., M. Santos de Lima, A.F. Morgor, and R. Goto. 2001. Production of iceberg lettuce using mulching. Sci. Agr. 58:737-740.

Waycott, W. and E.J. Ryder. 1992. Adaptation of lettuce to high-temperature environments, p. 285-295. In: C.G. Kuo (ed.). Proc. Intl. Symp. on Adaptation of Food Crops to Temperature and Water Stress. AVRDC, Shanhua, Tainan, Taiwan.

Whitaker, T.W., E.J. Ryder, V.E. Rubatsky, and P.V. Vail. 1974. Lettuce production in the United States. U.S. Dept. Agr. Hdbk. 221.

Wolfe, D.W., A.T. DeGaetano, G.M. Peck, M. Carey, L.H. Ziska, J. Lea-Cox, A.R. Kemanian, M.P. Hoffmann, and D.Y. Hollinger. 2018. Unique challenges and opportunities for northeastern U.S. crop production in a changing climate. Clim. Change 146:231-245. 